\title{
Dolerus (Poodolerus) zhelochovtsevi Heidemaa \& Viitasaari, 2009 new species for the Hungarian fauna
}

\author{
AtTILA Haris
}

H-1076 Budapest Garay u. 19. 2/20., Hungary, email: attilaharis@yahoo.com

Haris, A.: Dolerus (Poodolerus) zhelochovtsevi Heidemaa \& Viitasaari, 2009 new species for the Hungarian fauna.

Abstract: Dolerus (Poodolerus) zhelochovtsevi Heidemaa \& Viitasaari, 2009 is published from Tapolca as new record for the Hungarian fauna. Its description and genitalia figure is provided and its distribution is discussed.

Keywords: Hymenoptera, Symphyta, Tenthredinidae, Dolerus, new record, Hungary

\section{Introduction}

Based on the paper of Benson (1954) a rare Dolerus species was misidentified by HARIs (2019). The so far supposed male of Dolerus thoracicus (Fallén, 1808) (replacement name: Dolerus blanki Liston, 1995) now belongs to Dolerus (Poodolerus) zhelochovtsevi Heidemaa \& Viitasaari, 2009 based on genetic testings (Blank et al. 2009). Therefore, the communicated male in Haris (2019) is the male of Dolerus (Poodolerus) zhelochovtsevi Heidemaa \& Viitasaari, 2009 (instead of Dolerus blanki Liston, 1995).

\section{Material and methods}

In 2019, the author identified 1938 specimens of 197 sawfly species from the collection of the Bakony Natural History Museum in Zirc, amongst these species was the one which represent new record for the Hungarian fauna.

For original identification BENSON (1954) and HARIS (2000) were consulted. This year, this species was checked again using Heidemaa and Vitasari, 2005 (original description of the species) and MACEK et al. 2020.

Genitalia dissection and revision of the previously idenitfied species resulted new record for the Hungarian fauna, namely Dolerus (Poodolerus) zhelochovtsevi Heidemaa \& Viitasaari, 2009.

For the discussion of distribution of sawflies, we consulted the book of RoLLER and Haris (2008) titled Sawflies of the Carpathian Basin, History and Current Research augmented by other faunistic records from the Carpathian Basin (MóczÁR 1947, Scobiola-Palade 1967, 1978, Perovic et al. 2006 and Smetana et al. 2010). 


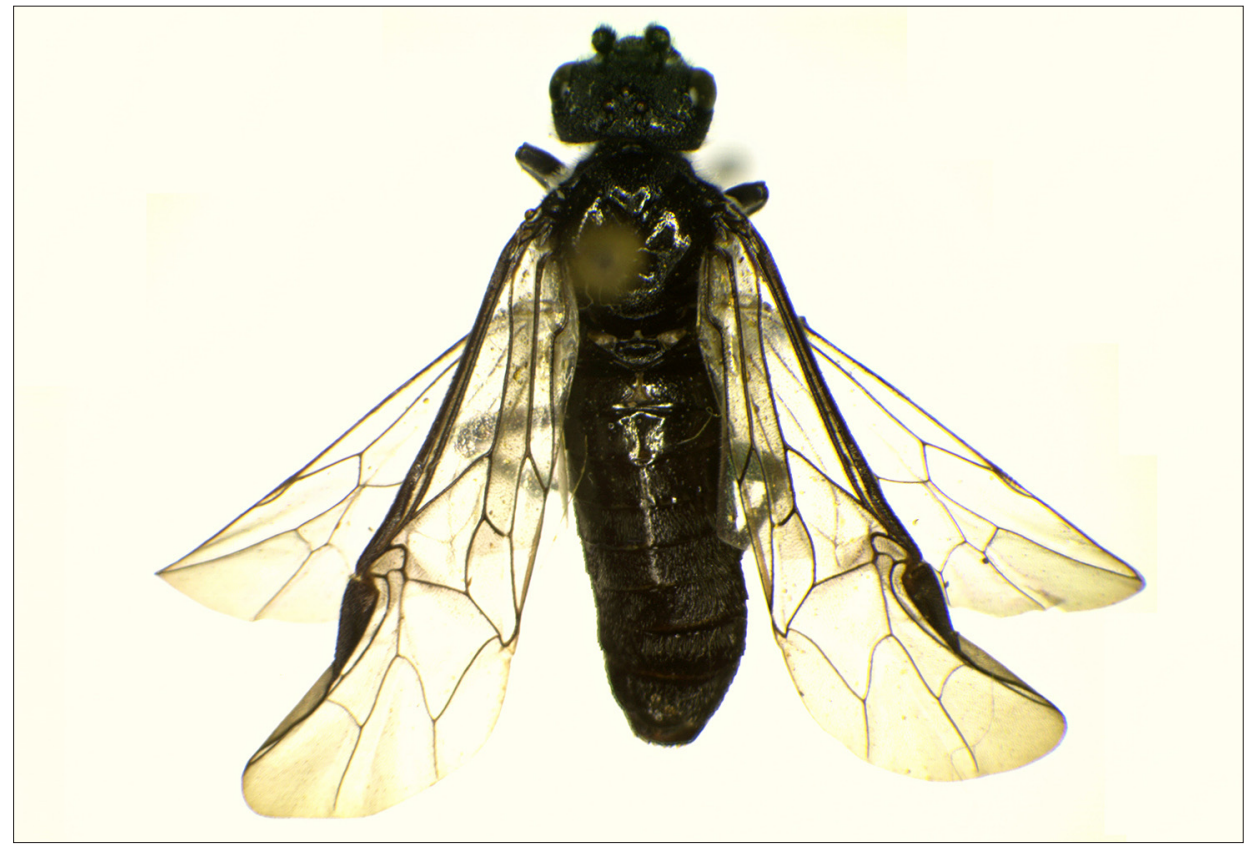

Fig. 1: Dolerus zhelochovtsevi Heidemaa \& Viitasaari, 2009

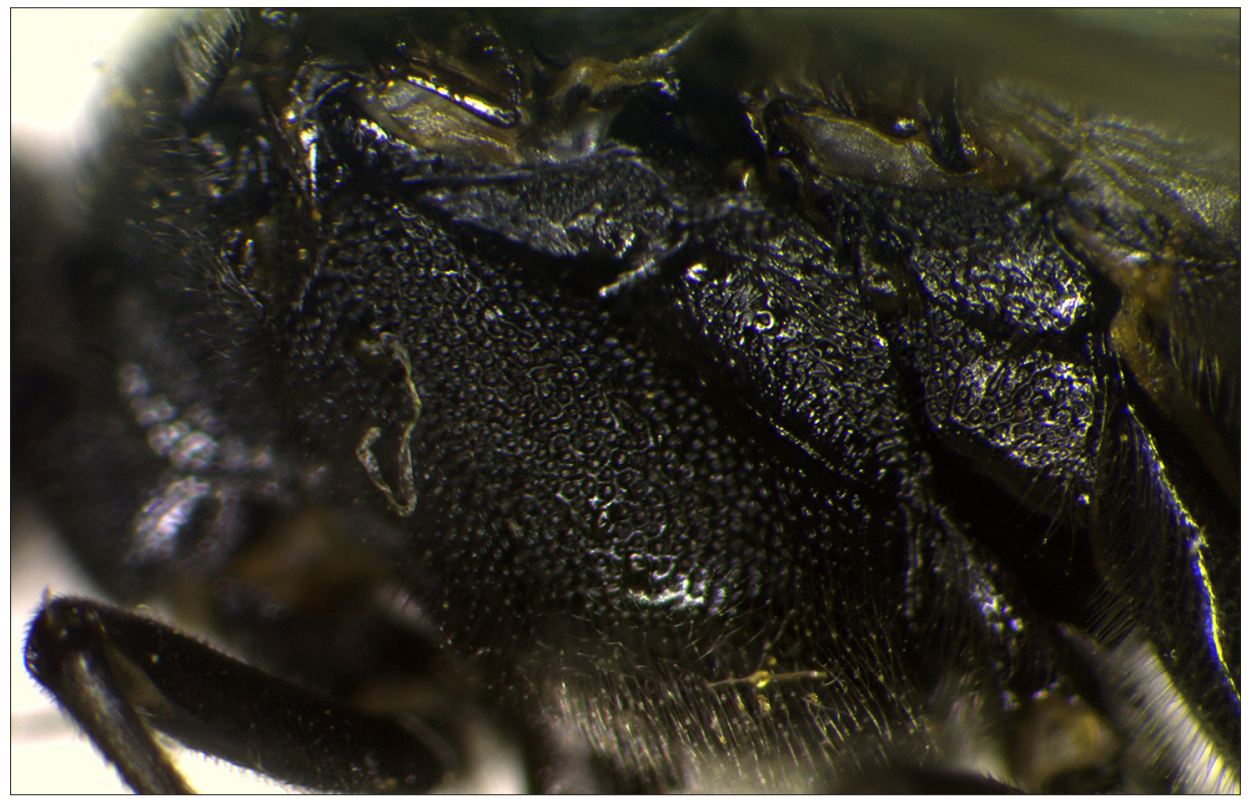

Fig. 2: Mesopleuron of Dolerus zhelochovtsevi Heidemaa \& Viitasaari, 2009 
Dolerus zhelochovtsevi Heidemaa and Vitasarii, 2005 (= Dolerus gibbosus auct.) is recorded from Magura (Scobiola-Palade 1967), Gyilkos tó (Lacu Rosu) (MóczÁr 1947), Nagyszeben (Sibiu), Pöltinis (Paltinis), Fogaras (Mt. Fagaras: lacul Bilea) (Scobiola-Palade 1978) from Transylvania, Tökös (Tikves) (Perovic et al. 2006) from North Croatia and Erdőhát (Záhorská nížina) from Slovakia. It is known from Austria, Czech Republic, Estonia, Finland, France, Germany, Macedonia, Poland, Russia, Slovakia, Sweden and Ukraine (TAEGER et al. 2006).

\section{Results}

Dolerus (Poodolerus) zhelochovtsevi Heidemaa \& Viitasaari, 2009 (Figs. 1, 2 and 3) Examined material: Tapolca 11. 03. 1990 leg. Lajos Németh.

\section{Description}

Male. Length: $10.6 \mathrm{~mm}$. Body black, cenchri brown. Wings hyaline, venation and stigma black, stgima with brown lower margin. Head and thorax covered with dense, white pubescence about as long as diameter of anterior ocellus. Head densely, roughly and deeply punctured, without shiny interspaces, gently shiny. OOL : POL : OCL: 17:8:12. Clypeus subtriangularly excised, clypeal excision about 0.33 as deep as clypeal median length. Head gently narrowed behind eyes. Anterior lobes of mesonotum, mesoscutellum and metascutellum densely, uniformly and deeply punctured with moderately large punctures, shiny with small shiny interspaces. Lateral lobes sporadically, moderately deeply punctured with moderately small punctures with large smooth and shiny areas. Mesopleuron densely, uniformly and deeply punctured, hardly shiny. Katepiumeron and metapleuron with rough coraceous sculpture. First tergite of abdomen smooth and shiny, other tergites with denses transverse surface sculpture. Hind margin of last abdominal tergite with smooth subtriangular area. Claws with small inner tooth.

For identification, genitalia dissection is necessary. Based on genitalia, this species can not be confused with any other species (Fig. 3).

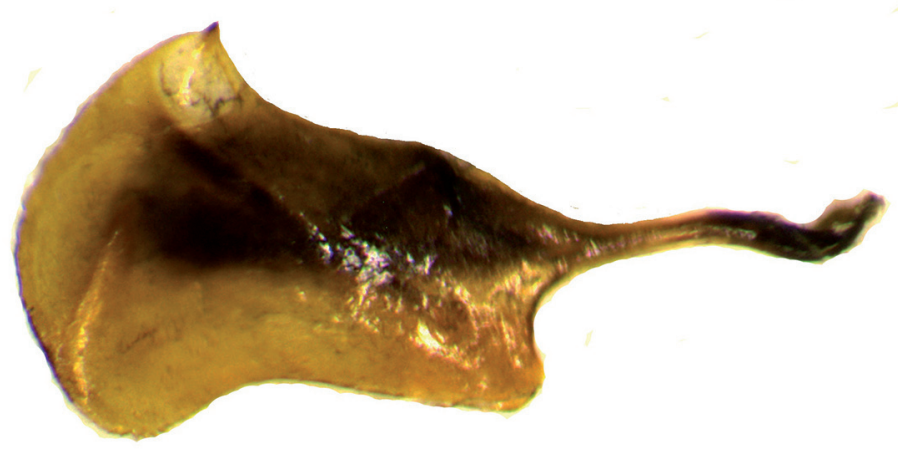

Fig. 3: Penis valve of Dolerus zhelochovtsevi Heidemaa \& Viitasaari, 2009 


\section{Acknowledgment}

Author expresses his grateful thanks to Dr. Levente Ábrahám (director, Rippl-Rónai Museum, Kaposvár) for his help in the microscopic photos, for reviewing and editing this paper.

\section{References}

Benson, R. B. 1954: Some sawflies of the European Alps and the Mediterranean Region (Hymenoptera, Symphyta). - Bulletin of the Natural History Museum (Ent.) 3(7): 269-295.

Blank, S. M., Taeger, A., Liston, A. D., Smith, D. R., Rasnitsyn, A. P., Shinohara, A., Heidemaa, M., ViITASAARI, M. 2009: Studies toward a World Catalog of Symphyta (Hymenoptera). - Zootaxa 2254: 1-96. https://doi.org/10.11646/zootaxa.2254.1.1

Haris, A. 2000: Study on the Palaearctic Dolerus Panzer, 1801 species (Hymenoptera: Tenthredinidae). - Folia Entomologica Hungarica Supplement 61: 95-148.

Haris, A. 2019: Sawflies of the Bakony Mountains and the Balaton Uplands (Hymenoptera: Symphyta). Natura Somogyiensis 34: 73-126. https://doi.org/10.24394/NatSom.2020.34.73

HeidemaA, M. \& Vittasaari, M. 2005: Taxonomy of the Dolerus gibbosus species group, with descriptions of Dolerus zhelochovtsevi, sp. nov., and males of D. blanki Liston, 1995, and D. quadrinotatus Biro, 1884, and redescription of the male of D. gibbosus Hartig, 1837 (Hymenoptera: Tenthredinidae) pp. 1-25. - In Heidemaa, M. Ed. Systematic Studies on Sawflies of the Genera Dolerus, Empria and Caliroa (Hymenoptera: Tenthredinidae) Dissertationes Biologicae Tartuensis, 99. Tartu 2004, 167 pp.

MaceK, J., Roller, L., Beneš, K. Holý, K. AND HolušA, J. 2020: Blanokřídlí České a Slovenské republiky II. Širopasí. - Academia Praha 669 pp.

MóczÁr, L. 1947: Beiträge zur Kenntnis der Hymenopterenfauna Siebenbürgens. - Fragmenta faunistica hungarica 10(2): 85-92.

Perovič, F., Merdic, E. \& Perovič, G. 2006 Sawflies (Hymenoptera, Symphyta) in the Biotopes of Kopacki Rit. - Natura Croatica 15 (4):189-201.

Roller, L. \& Haris, A. 2008: Sawflies of the Carpathian Basin, History and Current Research. - Natura Somogyiensis 11: 1-261. https://doi.org/10.24394/NatSom.2008.11.2

Scobiola-Palade, X. 1967: Catalogue of the collection of Hymenoptera (Tenthredinidae, Sphecidae and Pompiloidea) of the Brukenthal Museum (Department of Natural Sciences) in Sibiu, Rumania. (Monography). -Travaux du Museum d'Histoire Naturelle Grigore Antipa Bucharest 64 pp.

Scobiola-Palade, X. 1978: Hymenoptera Symphyta Tenthredinoidea, Tenthredinidae subf. Selandrinae, Tenthredininae, Heterarthrinae. - In: Fauna Republicii Socialiste România, Acad. Rep. Soc. Rom., Bucuresti, 9(8): 248.

Smetana, V., Roller, L., Benes, K., Bogusch, P., Dvorak, L., Holý, K., Karas, Z., Macek, J., Straka, J. Sima, P., Tyrner, P., Veprek, D., Zeman, V. 2010: Blanokrídlovce (Hymenoptera) na vybraných lokalitách borskei níziny. - Acta Musei Tekovensis Levice. Zborník tekovského Múzea v Leviciach 8: 78-111.

Taeger, A, Blank, S. M. \& Liston, A. 2006: European Sawflies (Hymenoptera: Symphyta) - A Species Checklist for the Countries 399-504. - In Blank, S. M., Schmidt, S. \& Taeger, A. (eds) Recent Sawfly Research: Synthesis and Prospects, Goecke \& Evers, Kelter. 701 pp. 